\title{
KEMAMPUAN BERPIKIR KRITIS MATEMATIK SISWA SMP PADA MATERI LINGKARAN
}

\author{
Indri Herdiman ${ }^{1}$, Ilfa Febrina Nurismadanti ${ }^{2}$, Pusparini Rengganis ${ }^{3}$, Neni Maryani ${ }^{4}$ \\ ${ }^{1}$ IKIP Siliwangi \\ herdiman0111@ikipsiliwangi.ac.id \\ ${ }^{2}$ IKIP Siliwangi \\ ilfafebrinan00@gmail.com \\ ${ }^{3}$ IKIP Siliwangi \\ pusparinirengganis@gmail.com \\ ${ }^{4}$ IKIP Siliwangi \\ nenimaryani26@yahoo.co.id
}

\author{
\begin{tabular}{l|l} 
Penerimaan : 9 Januari 2018 & Diterima: 2 Mei 2018
\end{tabular}
}

\begin{abstract}
The mathematical ability of critical thinking is a skill of person in determining a decision or solve a problem. The research is a qualitative descriptive study aimed analyze the mistakes of students in solving problem of mathematical critical thinking ability on Circle. Data collection techniques in this study conducted using tests such as about the description, the test is given to students of class IX in one of the Junior High School in the city of Cimahi. The results of this research show that most students have difficulty working on problem number 2 with indicators of reason and question number 5 with indicator of review and conclusion. After conducting the interview, the students say that they didn't understand the concept of formulas and also what kind of formulas to use in resolving the problems. Suggested in learning process, we should use learning strategies that can increased students' understand the concept, so that mathematical critical thinking ability can be achieved.
\end{abstract}

Keyword: Mathematical Critical Thinking Ability

\begin{abstract}
ABSTRAK
Kemampuan berpikir kritis matematik adalah keterampilan seseorang dalam menentukan suatu keputusan atau memecahkan masalah. Jenis penelitian ini adalah penelitian deskriptif kualitatif yang bertujuan untuk menganalisis kesalahan siswa dalam mengerjakan soal berpikir kritis matematik pada materi Lingkaran. Teknik pengambilan data pada penelitian ini dilakukan dengan menggunakan tes berupa soal uraian, soal diberikan kepada siswa kelas IX di salah satu SMP Negeri yang berada di Kota Cimahi. Hasil penelitian menunjukan bahwa kebanyakan siswa mengalami kesulitan mengerjakan soal nomor 2 dengan indikator alasan dan soal nomor 5 dengan indikator tinjauan ulang dan kesimpulan. Setelah melakukan wawancara, siswa mengatakan tidak memahami konsep dan juga rumus apa yang harus digunakan dalam menyelesaikan soal. Disarankan proses pembelajaran hendaknya menggunakan strategi pembelajaran yang dapat meningkatkan pemahaman konsep siswa, sehingga kemampuan berpikir kritis matematik dapat tercapai.
\end{abstract}

Kata Kunci : Kemampuan berpikir kritis matematik 


\section{PENDAHULUAN}

Berpikir adalah proses dimana seseorang menggunakan akalnya untuk memberikan gagasan atau suatu hal yang dikemukakan dengan informasi yang telah dia dapat atau telah dia ketahui sebelumnya untuk memecahkan suatu masalah. Menurut (Anggraeni \& Herdiman, 2018) dalam matematika yang disebut sebagai masalah biasanya merupakan soal-soal tidak rutin dimana diperlukannya kemampuan bernalar, berfikir kreatif, dan berfikir kritis dalam menyelesaikan masalahnya.

Selama ini, pembelajaran hanya berpusat pada guru yang menyampaikan materi, lalu siswa diberi soal tes untuk mengetahui pemahaman siswa terhadap apa yang disampaikan oleh guru di kelas. Sejalan dengan (Herdiman, 2017) Guru hendaknya memanfaatkan keberagaman cara atau prosedur untuk menyelesaikan masalah, agar memberi pengalaman kepada siswa dalam menemukan sesuatu yang baru berdasarkan pengetahuan, keterampilan, dan cara berpikir matematika yang telah diperoleh sebelumnya. Proses pembelajaran yang sering ditemukan di sekolah pada umumnya dilaksanakan untuk mencapai tujuan tingkat rendah yakni dalam mengetahui, memahami, dan menggunakan tetapi belum mampu menimbulkan kebiasaan berpikir kritis yaitu sesuatu yang paling esensi dari dimensi belajar. Dalam proses pembelajaran anak kurang di dorong dalam mengembangkan kemampuan berikir kritis matematik. Dengan demikian pembelajaran harus dirancang sedemikian sehingga dapat menumbuhkembangkan kemampuan berpikir kritis siswa (Sudiyasa, 2014).

Proses pembelajaran selama ini masih dididominasi oleh guru sehingga belum memberikan keleluasaan bagi siswa untuk berkembang secara mandiri melalui penemuan dan proses berpikir. Guru selalu menuntut siswa untuk belajar, tetapi tidak mengajarkan bagaimana siswa seharusnya belajar dan menyelesaikan masalah (Setyorini, Sukiswo, \& Subali, 2011). Siswa tidak dilatih untuk berpikir kritis sehingga siswa hanya menghapal tanpa tahu konsep dari materi yang telah dipelajari. Hal ini sejalan dengan pendapat Indarti (2014) yang menyatakan bahwa kemampuan berpikir kritis matematis siswa sangat rendah karena jarang dipergunakan dikelas bahkan tidak pernah. Selama ini para siswa kurang dilatih sehingga untuk pengambilan keputusan ragu terutama berpikir kritis matematis. Juga sejalan dengan pendapat Jayadipura (2014) yang mengatakan bahwa pada saat ini pelaksanaan pembelajaran matematika dan evaluasinya belum menekankan pada pengembangan kemampuan berpikir kritis, dan lebih banyak melatih siswa pada kemampuan prosedural, low order thinking skills, melalui latihan soal rutin, dan pertanyaan tingkat rendah. 
Kemampuan berpikir kritis matematis yang ada dalam diri siswa harus dikembangkan dengan baik. Agar terwujudnya visi pendidikan matematika menurut Sumarmo (Indarti, 2014), yaitu siswa memiliki kemampuan matematik memandai, bepikir dan bersikap kritis, kreatif dan cermat, objektif dan terbuka, menghargai, keindahan matematika, serta rasa ingin tahu. Selain dari itu, siswa dapat juga memahami konsepkonsep matematika dan mengaplikasikannya dalam berbagai soal matematika. Karena pada dasarnya, pengerjaan soal matematika tidak cukup hanya dengan menalar saja. Diperlukan kemampuan berpikir yang dapat mendorong motivasi siswa dalam mengerjakan soal-soal dengan tepat.

Kemampuan berpikir kritis adalah salah satu tujuan keberhasilan dalam pembelajaran matematika. Proses belajar mengajar menggunakan berpikir kritis merupakan proses berpikir tingkat tinggi, sejalan dengan pendapat (Sumarmo, Hidayat, Zukarnaen, Hamidah, \& Sariningsih, 2012) "Dalam berpikir kritis memuat semua komponen berpikir tingkat tinggi, namun juga memuat disposisi kritis yang tidak termuat dalam berpikir tingkat tinggi”. Menurut Ennis (Sunaryo, 2013) menyatakan bahwa dalam berpikir kritis ada 6 indikator : (1) Fokus,yaitu memahami masalah dan menentukan hal dalam masalah tersebut, (2) Alasan, yaitu memberikan alasan dalam menawab atau menyimpulkan, (3) Simpulan, yaitu memperkirakan kesimpulan yang akan didapat, (4) Situasi, yaitu menerapkan konsep pengetahuan yang sebelumnya dimiliki untuk menyelesaikan masalah pada situasi yang sudah ada, (5) Kejelasan, yaitu menyajikan masalah atau soal yang serupa dengan yang sudah ada, (6) Pemeriksaan atau Tinjauan, yaitu memeriksa kebenaran jawaban.

Berdasarkan uraian di atas, maka peneliti akan mengkaji tentang kesalahan yang dilakukan oleh siswa dalam menyelesaikan soal berpikir kritis khususnya pada materi lingkaran untuk siswa SMP.

\section{METODOLOGI PENELITIAN}

Penelitian ini merupakan penelitian deskriptif kualitatif yang bertujuan untuk menganalisis kesalahan siswa pada saat menjawab soal-soal berpikir kritis pada materi lingkaran. Penelitian dilaksanakan di salah satu SMP Negeri di Kota Cimahi pada bulan November 2017 dengan subjek penelitian adalah siswa kelas IX. Pemilihan subjek dalam penelitian ini berdasarkan rekomendasi dari pihak sekolah dengan pertimbangan kemampuan siswa di kelas tersbut heterogen, dimana kemampuan siswa rendah, sedang 
dan tinggi tersebar secara merata. Lalu diperoleh satu kelas dengan jumlah sebanyak 36 siswa. Setelah dianalisa diperoleh 3 orang siswa yang nilainya paling tinggi, nilai sedang, dan nilai yang paling rendah, yang kemudian akan diwawancara untuk menambah informasi tentang hambatan siswa saat mengerjakan soal lingkaran.

Langkah-langkah dalam penelitian ini terdapat 3 tahap, yaitu: (1) Persiapan, yaitu mengkaji permasalahan yang ada dilapangan, menyusun latar belakang dan kajian teori, mempersiapkan instrumen penelitian, mengurus perizinan dengan mendatangi Wakasek Kurikulum sekaligus memberikan administrasi, dan menentukan jadwal penelitian yang disertai oleh guru mata pelajaran dan peneliti. (2) Pelaksanaan, yaitu memberikan tes kemampuan berpikir kritis, dan mewawancara beberapa orang siswa terkait pengerjaan soal tes. (3) Evaluasi, yaitu mengumpulkan data yang diperoleh pada saat penelitian (dari soal tes dan wawancara), mengolah dn menganalisis data hasil penelitian, dan menyimpulkan hasil penelitian yang telah dilakukan.

Instrumen dalam penelitian ini adalah seperangkat soal tes uraian yang terdiri dari 5 soal yang dapat mengukur kemampuan berpikir kritis matematik siswa diadopsi soal tersebut dari penelitian Kurniawan (2017) yang telah mempunyai validitas isi dan validitas empiris, lalu dengan wawancara kepada beberapa orang siswa dengan kemampuan heterogen ysng mewakili kemampuan rendah, sedang, dan tinggi. Analisis penelitian ini merupakan hasil tes kemampuan berfikir kritis matematik dengan mengacu kepada rubrik pemberian skor menurut Susilawati (2014). Dari hasil tes tertulis, kemudian dihitung presentase skor masing-masing tahapan tiap butir soal.

$$
\mathrm{P}=\frac{\mathrm{T}}{S \times N} \times 100 \%
$$

\section{Keterangan:}

$\mathrm{P}$ : Persentase skor masing-masing tahapan tiap butir soal

$\mathrm{T}$ : Total skor masing-masing indikator tiap butir soal seluruh subjek

$\mathrm{S}$ : Skor maksimum masing-masing indikator tiap butir soal

$\mathrm{N}$ : Banyak subjek 


\section{HASIL DAN PEMBAHASAN}

Setelah melakukan tes tertulis sebanyak lima soal berpikir kritis yang berbentuk uraian, diperoleh hasil penskoran dari hasil jawaban siswa yang disajikan pada tabel 1.

Tabel 1. Rekapitulasi Hasil Tes Kemampuan Berpikir Krtis

\begin{tabular}{|c|c|c|c|c|c|c|c|c|}
\hline \multirow[t]{2}{*}{ Indikator } & \multirow[t]{2}{*}{$\begin{array}{c}\text { Nomor } \\
\text { Soal }\end{array}$} & \multicolumn{2}{|c|}{$\begin{array}{c}\text { Jawaban } \\
\text { Benar }\end{array}$} & \multicolumn{2}{|c|}{$\begin{array}{c}\text { Jawaban } \\
\text { Kurang } \\
\text { Tepat atau } \\
\text { Salah } \\
\end{array}$} & \multicolumn{2}{|c|}{$\begin{array}{c}\text { Tidak Ada } \\
\text { Jawaban }\end{array}$} & \multirow[t]{2}{*}{$\begin{array}{c}\text { Presentase Skor } \\
\text { Siswa Perbutir } \\
\text { Soal }(\%)\end{array}$} \\
\hline & & $\mathrm{N}$ & $\%$ & $\mathrm{~N}$ & $\%$ & $\mathrm{~N}$ & $\%$ & \\
\hline Fokus & 1 & 4 & 11,11 & 32 & 88,89 & 0 & 0 & 41,7 \\
\hline Alasan & 2 & 0 & 0 & 29 & 80,56 & 7 & 19,44 & 18,9 \\
\hline $\begin{array}{c}\text { Alasan \& } \\
\text { Situasi }\end{array}$ & 3 & 14 & 38,89 & 22 & 61,11 & 0 & 0 & 59,4 \\
\hline Kejelasan & 4 & 4 & 11,11 & 29 & 80,56 & 3 & 8,33 & 27,2 \\
\hline $\begin{array}{c}\text { Tinjauan } \\
\text { Ulang \& } \\
\text { Kesimpulan }\end{array}$ & 5 & 0 & 0 & 28 & 77,78 & 8 & 22,22 & 16,1 \\
\hline
\end{tabular}

Dari tabel 1 dapat dilihat pada hasil pengerjaan soal nomor 1 dengan indikator fokus, terdapat $11,11 \%$ siswa yang dapat menjawab soal dengan jawaban benar, $88,89 \%$ siswa yang menjawab kurang tepat atau salah, dan tidak ada siswa yang tidak menjawab sama sekali. Ini berarti hampir seluruh siswa mengalami kesulitan dalam menjawab soal nomor 1. Hasil rata-rata presentase skor seluruh siswa pada soal nomor 1 adalah $41,7 \%$ dengan kualifikasi capaian kurang. Pada soal nomor 2 dengan indikator alasan, tidak terdapat siswa yang dapat menjawab benar, $80,56 \%$ siswa menjawab kurang tepat dan salah, serta 19,44\% siswa tidak menjawab. Ini berarti seluruh siswa kesulitan dalam menyelesaikan soal nomor 2. Hasil rata-rata presentase skor seluruh siswa pada soal nomor 1 adalah 18,9 \% dengan kualifikasi capaian sangat kurang.

Pada soal nomor 3 dengan indikator alasan dan situasi, terdapat 38,89\% siswa dapat menjawab soal dengan benar, $61,11 \%$ siswa menjawab soal kurang tepat dan salah, dan tidak ada siswa yang tidak menjawab sama sekali. Ini berarti beberapa siswa tidak mengalami kesulitan dalam menjawab soal nomor 3. Hasil rata-rata presentase skor seluruh siswa pada soal nomor 1 adalah 59,4 \% dengan kualifikasi capaian cukup. Pada soal nomor 4 dengan indikator kejelasan, terdapat $11,11 \%$ siswa menjawab benar, $80.56 \%$ siswa menjawab dengan kurang tepat atau salah dan $8,33 \%$ siswa tidak dapat menjawab soal sama sekali. Ini berarti hampir seluruh siswa mengalami kesulitan dalam menjawab soal nomor 4. Hasil rata-rata presentase skor seluruh siswa pada soal nomor 4 adalah 27,2 \% dengan kualifikasi capaian sangat kurang. Pada soal nomor 5 dengan indikator tinjauan 
ulang dan kesimpulan tidak terdapat siswa yang menjawab dengan benar, 77,78\% siswa menjawab kurang tepat atau salah, dan $22,22 \%$ siswa tidak menjawab sama sekali. Ini berarti hampir seluruh siswa mengalami kesulitan dalam menjawab soal nomor 5. Hasil rata-rata presentase skor seluruh siswa pada soal nomor 5 adalah 16,1 \% dengan kualifikasi capaian sangat kurang.

Salah satu hasil pekerjaan siswa yang kurang tepat pada soal nomor satu dengan indikator fokus disajikan pada gambar 1.

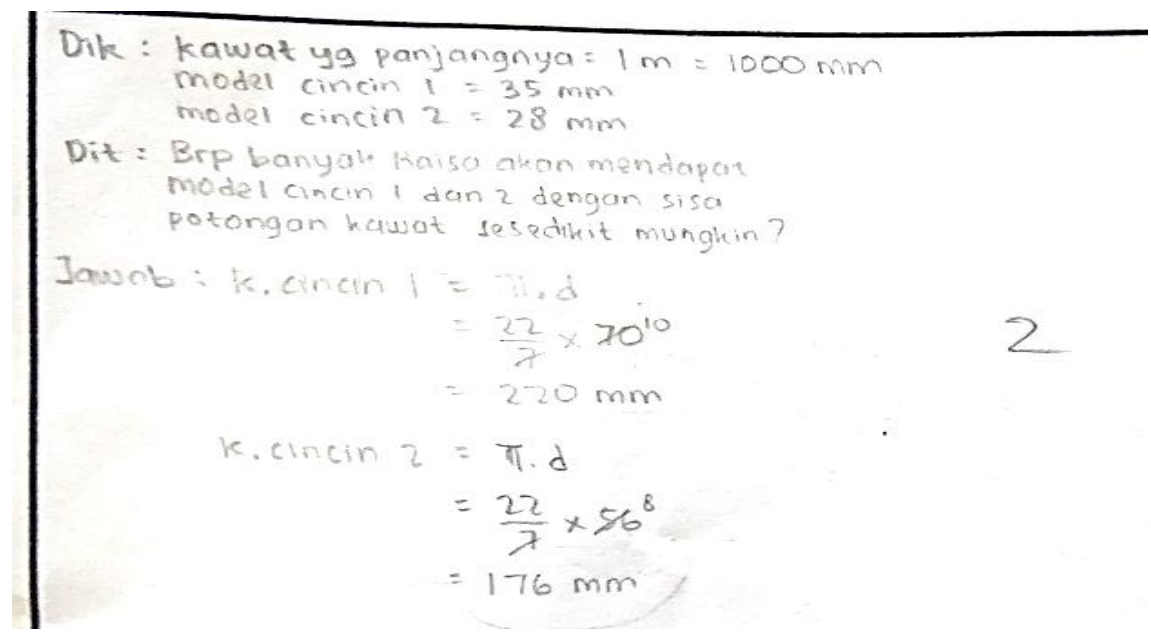

Gambar 1. Hasil pekerjaan siswa pada soal nomor satu.

Berdasarkan gambar 1 terlihat beberapa kesalahan pekerjaan siswa pada soal nomor satu, yaitu siswa hanya melengkapi data pendukung atau mengidentifikasi soal dan menentukan aturan umum tetapi salah dalam proses perhitungan dan tidak memberikan kesimpulan. Berdasarkan hasil wawancara, siswa dengan kemampuan tinggi siswa tidak mengalami kesulitan dalam pengerjaan penyelesaian masalah, siswa dengan kemampuan sedang mengalami kesulitan dalam menentukan aturan umum untuk menyelesaikan masalah sehingga hasilnya salah dikarenakan siswa tidak teliti dalam mengidentifikasi soal, dan siswa dengan kemampuan rendah mengalami kesulitan dalam malanjutkan pengerjaan ke tahap selanjutnya karena siswa tidak teliti dalam mengidentifikasi soal. 
Salah satu hasil pekerjaan siswa yang kurang tepat pada soal nomor dua dengan indikator alasan disajikan pada gambar 2.

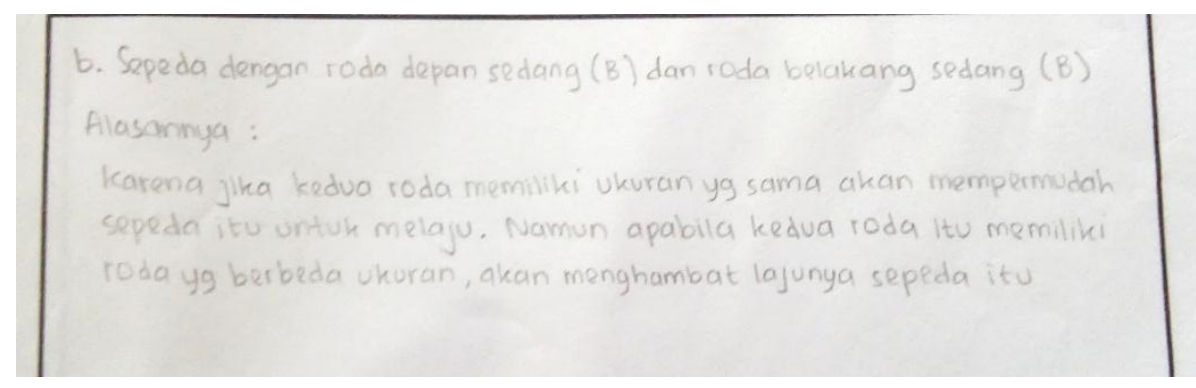

Gambar 2. Hasil pekerjaan siswa pada soal nomor dua

Dapat dilihat beberapa kesalahan pekerjaan siswa pada soal nomor dua pada gambar 2. kesalahan yang dibuat adalah siswa tidak melengkapi data dan tidak mengidentifikasi soal dengan baik dan hanya menyimpulkan tanpa memberi penjelasan yang logis . Dari hasil wawancara, siswa dengan kemampuan rendah, sedang, dan tinggi, ketiganya mengatakan bahwa mereka tidak dapat memahami soal dengan baik sehingga hanya menjawab berdasarkan logika saja.

Salah satu hasil pekerjaan siswa yang kurang tepat pada soal nomor tiga dengan indikator alasan dan situasi disajikan pada gambar 3.

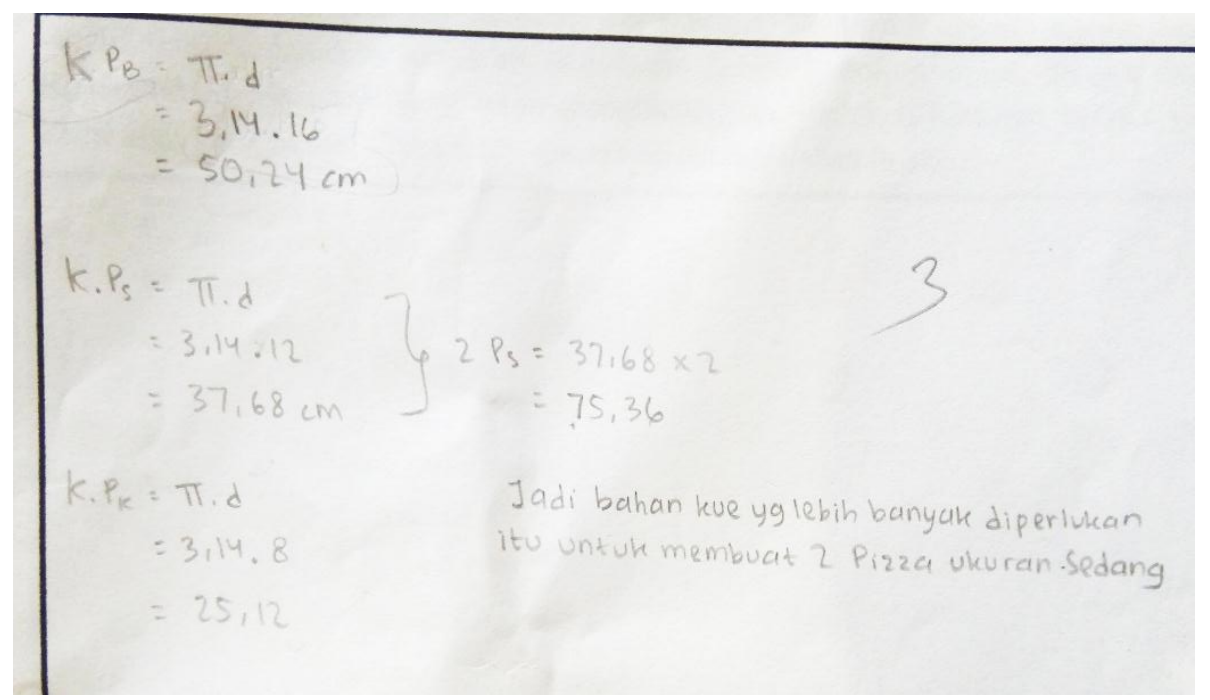

Gambar 3. Hasil pekerjaan siswa pada soal nomor tiga

Terlihat pada gambar 3, kesalahan yang dibuat yaitu beberapa siswa salah dalam menentukan aturan umum sedangkan beberapa siswa salah dalam memasukkan data ke dalam aturan atau rumus. Hasil wawancara memperlihatkan bahwa siswa dengan kemampuan tinggi tidak mengalami kesulitan dalam pengerjaan, siswa berkemampuan rendah mengalami kesulitan mengubah situasi menjadi model matematika sehingga salah 
saat menentukan aturan umum untuk menyelesaikan masalah, sedangkan siswa berkemampuan rendah hanya bisa mengidentifikasi soal tetapi tidak bisa menyelesaikan model matematika yang telah dibuat, sehingga dalam penarikan kesimpulan, siswa hanya menggunakan logika berdasarkan model matematika yang telah dibuat.

Salah satu hasil pekerjaan siswa yang kurang tepat pada soal nomor empat dengan indikator kejelasan disajikan pada gambar 4.

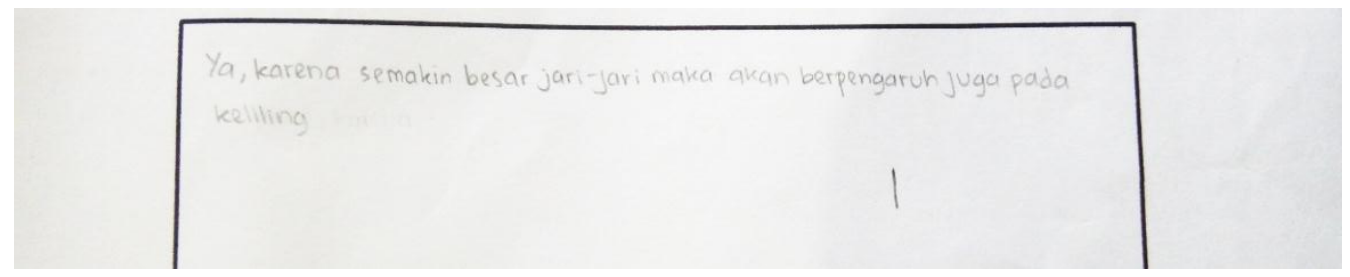

Gambar 4. Kasil pekerjaan siswa pada soal nomor empat

Dapat dilihat hasil pekerjaan siswa untuk soal nomor empat, kesalahan siswa yaitu tidak memberikan penjelasan dan hanya mencantumkan kesimpulan. Berdasarkan hasil wawancara siswa dengan kemampuan tinggi tidak kesulitan dalam menyelesaikan permasalahan, siswa dengan kemampuan sedang dan rendah mengalami kesulitan dalam menentukan aturan umum untuk memberikan penjelasan terhadap kesimpulan yang mereka buat.

Salah satu hasil pekerjaan siswa yang kurang tepat pada soal nomor lima dengan indikator tinjauan ulang dan kesimpulan disajikan pada gambar 5.

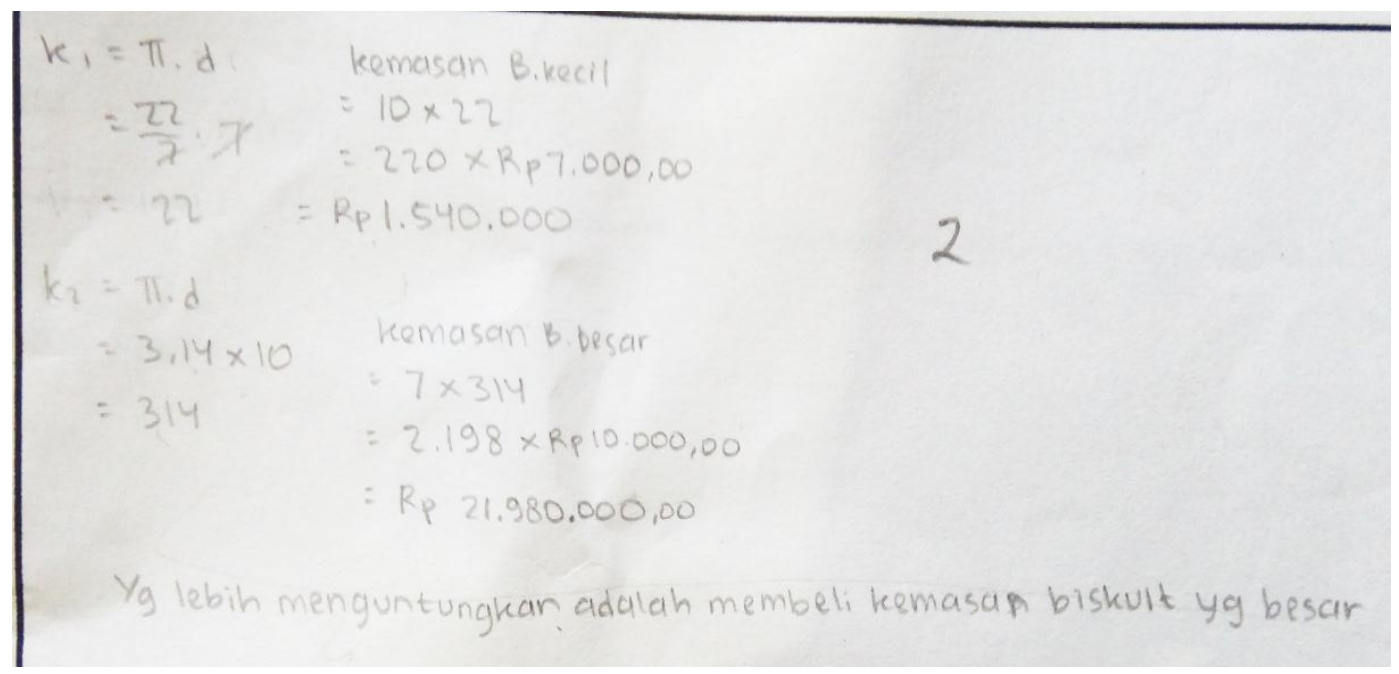

Gambar 5. Hasil pekerjaan siswa pada soal nomor lima

Pada gambar 5 terlihat kesalahan pekerjaan siswa pada nomor lima yakni pada penentuan aturan umum yang akan digunakan dan hanya membuat model matematika 
tetapi hasilnya salah. dari hasil wawancara, ketiga siswa yaitu siswa dengan kemampuan rendah, sedang dan tinggi kesulitan saat mengidentifikasi soal dengan baik.

Berdasarkan pembahasan tersebut, dapat dilihat bahwa kesulitan yang paling banyak dihadapi siswa terdapat pada soal nomor 2 dan nomor 5, dengan indikator alasan, tinjauan ulang, dan kesimpulan. Pada nomor 2 dan nomor 5 siswa masih mendapat kesulitan dalam penyelesaian masalah awal dalam menentukan rumus yang akan digunakan saat menyelesaikan soal dan tidak dapat memahami permasalahan yang diberikan. Hal ini diperkuat oleh hasil wawancara dengan siswa yang menyatakan bahwa siswa mengalami kesulitan pada soal nomor 2 dan 5. Kesulitan yang dialami oleh siswa yaitu tidak mengetahui rumus apa yang harus digunakan saat perhitungan, serta hanya bias menyimpulkan berdasarkan logika.

\section{KESIMPULAN}

Berdasarkan penelitian dan analisis yang telah dilaksanakan, kemampuan berpikir kritis matematik siswa masih sangat rendah. Pada penelitian in, siswa belum mencapai indikator kemampuan befikir kritis matematik, khususnya dalam pencapaian indikator alasan, tinjauan ulang, dan kesimpulan. Siswa dirasa belum bisa memberikan alasan atau kesimpulan yang logis dalam menyelesaikan masalah. Kurangnya pemahaman siswa disaat menentukan rumus awal dan menentukan penyelesaian secara sistematis dalam menyesaikan masalah.

Berdasarkan uraian di atas, dikemukakan saran diperlukannya penerapan strategi pembelajaran yang dapat meningkatkan kemampuan berpikir kritis matematik siswa yang memiliki karakteristik : (1) pembelajaran berfokus pada proses belajar, bukan hasil belajar, (2) mengeksprolasi pengetahuan siswa melalui proses berpikir, (3) merefleksi proses pembelajaran sehingga tercapai tujuan pembelajaran yang mendorong siswa untuk mencapi indikator pada kemampuan berpikir krisis matematik siswa khususnya indikator alasan, tinjauan ulang, dan kesimpulan yang dalam prnrlitian ini dirasa masih kurang. 


\section{REFERENSI}

Anggraeni, R., \& Herdiman, I. (2018). Kemampuan Pemecahan Masalah Matematik Siswa SMP Pada Materi Lingkaran Berbentuk Soal Kontekstual Ditinjau dari Gender. Jurnal Numeracy, 5(1), 19-28.

Herdiman, I. (2017). Peenerapan Pendekatan Open-Ended untuk Meningkatkan Matematik Siswa SMP. JES-MAT, 3(2), 195-204.

Indarti, S. M. (2014). Peran Kemampuan komunikasi dan Berpikir Kritis Matematis Serta Kemandirian Belajar Siswa SMA Menggunakan Pendekatan Pembelajaran Berbasis Masalah. In Prosiding Seminar Nasional Pendidikan Matematika Program Pasca Sarjana STKIP Siliwangi Bandung (Vol. 1, pp. 119-124).

Jayadipura, Y. (2014). Mengukur Kemampuan Berpikir Kritis Matematik. In Prosiding Seminar Nasional Matematika STKIP Siliwangi Bandung (Vol. 1, pp. 125-130).

Kurniawan, A. (2017). Penerapan Pendekatan Problem Based Learning untuk Meningkatkan Kemampuan Berfikir Kritis Matematik Siswa SMP. Skripsi STKIP Siliwangi Bandung: tidak diterbitkan

Setyorini, U., Sukiswo, S. E., \& Subali, B. (2011). Penerapan Model Problem Based Learning Untuk Meningkatkan Kemampuan Berpikir Kritis Siswa SMP. Jurnal Pendidikan Fisika Indonesia (Indonesian Journal of Physics Education), 7(1), 52-56. Retrieved from http://journal.unnes.ac.id/nju/index.php/JPFI

Sudiyasa, I. W. (2015). Mengembangkan Kemampuan Berpikir Kritis dengan Pembelajaran Berbasis Masalah. Prosiding Seminar Nasional Pendidikan Matematika Program Pasca Sarjana STKIP Siliwangi Bandung Vol. 1 Hlm. 157-160.

Sumarmo, U., Hidayat, W., Zukarnaen, R., Hamidah, M., \& Sariningsih, R. (2012). Kemampuan dan Disposisi Berpikir Logis, Kritis, dan Kreatif Matematik (Eksperimen terhadap Siswa SMA Menggunakan Pembelajaran Berbasis Masalah dan Strategi Think-Talk-Write). Jurnal Pengajaran Matematika Dan Ilmu Pengetahuan Alam, 17(1), 17-33. https://doi.org/10.18269/jpmipa.v17i1.228

Sunaryo, Y. (2013). Tasikmalaya, Model pembelajaran berbasis masalah untuk meningkatkan kemampuan berpikir kritis dan kreatif matematik siswa sma di kota. (Doctoral dissertation, Universitas Terbuka).

Susilawati, W. (2014). Belajar dan Pembelajaran Matematika. Bandung: Insan Mandiri. 